\title{
Assessment of Internal Radiation Dose in Gastro Intestinal Tract for Acute Ingestion of Ra-226 of the People of Bangladesh
}

\author{
${ }^{1}$ A H M R Quddus, ${ }^{2}$ M M A Zaman, ${ }^{3}$ A S Mollah and ${ }^{4} M$ M Zaman \\ ${ }^{1}$ Department of Physics, National University, Gazipur \\ ${ }^{2}$ Department of Physics, Jahangirnagar University, Savar, Dhaka \\ ${ }^{3}$ Department of Nuclear Science and Engineering, MIST, Dhaka \\ ${ }^{4}$ Army Education Corps, Bangladesh Army
}

Correspondence Address: AHM R Quddus, Physics Department, National University, Gazipur, Bangladesh, E-mail: rqbd73@gmail.com

\begin{abstract}
To design appropriate method for treatment planning it is necessary to know the precise radiation dose absorbed by any internal organ in human body. This paper will provide a method for calculating retention, absorbed dose, committed equivalent dose and committed effective doses due to acute ingestion of 1 Bq of Ra-226 in the gastro intestinal (GI) tract of Bangladeshi people for different age groups. Calculations are done by using "Internal Radiation Dose Assessment (IRDA)" software which has been developed in Visual Basic language. GI tract consists of four tissue compartments, e.g. stomach (ST), small intestine (SI), upper large intestine (ULI) and lower large intestine (LLI). One hour after the ingestion, the retention and absorbed dose show the trend ST > SI > ULI > LLI. For tissue compartments the variation of the committed equivalent dose pattern is LLI > ULI $>$ ST > SI for the radionuclide. The variation of absorbed dose, committed equivalent dose and committed effective dose with respect to age follow the pattern: 1 year $>10 y e a r s>$ adult female $>$ adult male. The highest committed effective dose is found in the GI tract of 1 year old child. For other age groups these values are slightly less than those for $\mathbf{1}$ year old child.
\end{abstract}

Key Words: IRDA, Absorbed dose, Committed effective dose.

\section{INTRODUCTION}

Because of increasing application of nuclear industries and nuclear medicine it is important to assess and control both external and internal radiation doses of occupational workers and evaluate the trend of radiation exposure to members of the general population. For this purpose proper monitoring methods should be set. Together with it, it will be worth to know the values of dose rate, which, might be transferred from environmental media into foodstuffs and subsequently ingested by members of the public. In the present work calculations have been done for internal radiation doses due to acute intake of Ra-226 radioisotope through ingestion by radiation workers/public considering biological aspects of Bangladeshi people. Additionally the data have been used for the calculation of committed equivalent dose and committed effective dose in GI tract. For intakes by ingestion, the GI tract model (1) is used to calculate the dose coefficients. It describes movement of radionuclides through four regions: stomach (ST), small intestine (SI), upper large intestine (ULI) and lower large intestine (LLI) of the GI tract with parameter values for assessing the radiation dose to walls of the stomach and gut. The biokinetic models of the ICRP for systemic activity $(2,3)$ were used for calculating dose coefficients for intakes by ingestion.

\section{MATERIALS AND METODS}

In the present work calculations have been done by using IRDA $(4,5)$ software for retention, absorbed dose, equivalent dose and committed effective dose from acute intake of $1 \mathrm{~Bq}$ of Ra-226. Tissue masses of GI tract for Bangladeshi people have been considered to calculate the above mentioned quantities for different age groups 1 year, 10 years and adult (female and male). The software was developed in Visual Basic language following GI tract model (1). The mathematical function describing uptake and retention of a radionuclide in a body tissue following its ingestion is described for 
ST, SI, ULI and LLI tissue compartment (figure 1). Loss of radionuclide from one compartment is taken to be governed by the first order kinetics. Therefore the retention of an element in any tissue will usually be described by either single exponential term or the sum of a number of exponential terms (1).

The rate of translocation to the body fluids after the radionuclide has been ingested depends on the rate constants $\left(\lambda_{B}\right)$ for the different compartments in the GI tract system and the radioactive decay constant $\left(\lambda_{R}\right)$ of the radionuclide which can be mentioned by the following flow chart:

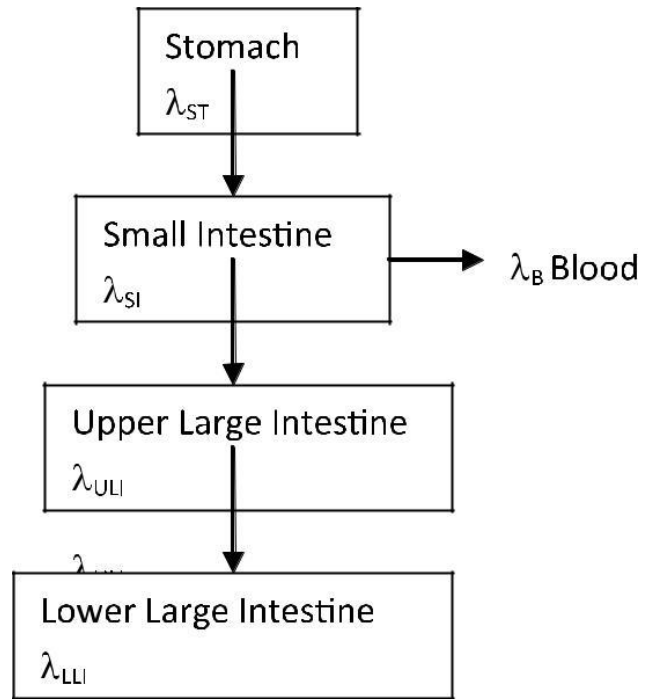

Figure 1 Different parts of GI tract and biological transfer routes of radionuclides

The rate of dose absorbed to a particular organ or tissue after a certain time of acute intake is given by

$\mathrm{D}(\mathrm{t})==1.6 \times 10^{-10} \sum_{s}\left[q_{S}(t) \sum S E E(T \leftarrow S)_{j}\right]_{j}$ in $\mathrm{mSv}$

Here, $q_{S}(t)$ is the retention at particular compartment $S$, after a certain time of a particular radionuclide $j$, from the acute intake. Summation in $S$ is due to irradiation of target organ $\mathrm{T}$ by radiations arising in several different sources $\mathrm{S}$.

SEE $(T \leftarrow S)_{i}$ is the specific effective energy from radiation of type $i$ originating in $S$.
For a particular radionuclide $\mathrm{j}$, the term is given by

SEE $(\mathrm{T} \leftarrow S)_{\mathrm{i}}=\frac{Y_{i} E_{i} A F(T \leftarrow S)_{i} Q_{i}}{M_{T}} \mathrm{MeV} \mathrm{kg}^{-1}$ per transformation (2)

Here, $\mathrm{Ei} \mathrm{(in} \mathrm{MeV)} \mathrm{is} \mathrm{the} \mathrm{average,} \mathrm{or} \mathrm{unique} \mathrm{energy} \mathrm{of}$ radiation $\mathrm{i}, \mathrm{AF}(\mathrm{T} \leftarrow S)$ is the average fraction of energy absorbed in target organ $\mathrm{T}$ from radiation arising in source organ $\mathrm{S}, \mathrm{Y}_{\mathrm{i}}$ is the yield of radiations of type i per transformation of radionuclide $j, Q_{i}$ is the quality factor appropriate for radiation $\mathrm{i}$, and $\mathrm{M}_{\mathrm{T}}$ (in $\mathrm{g}$ ) is the mass of the target organ.

Committed dose equivalent $\mathrm{H}_{50, \mathrm{i}}$ for each type of radiation $i$, in target $T$ resulting from radionuclide $j$ in source $\mathrm{S}$ is the product of the two factors. These are the total number of transformation of radionuclide $\mathrm{j}$ in $\mathrm{S}$ over whole life time after intake, and $\mathrm{SEE}(\mathrm{T} \leftarrow \mathrm{S})_{\mathrm{i}}$ i.e., for each radiation of type $i$ from radionuclide $j$.

$\mathrm{H}_{50}(\mathrm{~T} \leftarrow \mathrm{S})_{\mathrm{i}}=\mathrm{U}_{\mathrm{S}} \times 1.6 \times 10^{-10} \times \mathrm{SEE}(\mathrm{T} \leftarrow \mathrm{S})_{\mathrm{I}} \mathrm{mSV}$

here $U_{S}$ is the number of transformation of $j$ in $S$ over 50 years following intake of the radionuclide; for all type of radiation emitted by radionuclide $\mathrm{j}$

$\mathrm{H}_{50}(\mathrm{~T} \leftarrow \mathrm{S})_{\mathrm{i}}=1.6 \times 10^{-10}\left[U_{s} \sum_{i} S E E(T \leftarrow S)_{i}\right]_{i} m S v$

Committed Effective Dose for the GI tract is the summation over the product of committed equivalent dose and tissue weighting factor $\left(\mathrm{W}_{\mathrm{t}}\right)$

$\mathrm{E}(\tau)=\sum_{t} H \times W_{t} \mathrm{mSv}$

\section{RESULTS AND DISCUSSION}

The retention variation (Figure 2) for the radionuclide Ra-226 is characterized by the initial falling rate for ST but for SI, ULI and LLI retention shows initial rising after which, it decreases exponentially. The transfer of radionuclide from oral cavity to the stomach has been considered an instantaneous process which gives no retention in the entry route. The maximum deposition in SI, ULI and LLI are about $0.58 \mathrm{~Bq}, 0.50 \mathrm{~Bq}$ and $0.37 \mathrm{~Bq}$ after $2 \mathrm{hrs}, 8 \mathrm{hrs}$ and $24 \mathrm{hrs}$ of ingestion respectively. From all these tissue compartments retention decreases exponentially, because of exponential rate of excretion 
from one compartment to the other compartment.

Table 1 and Figure 3 to Figure 6 show the variation of dose values from intake to 48 hours of ingestion. The variation of absorbed dose per hour for 10 years old person is discussed below:

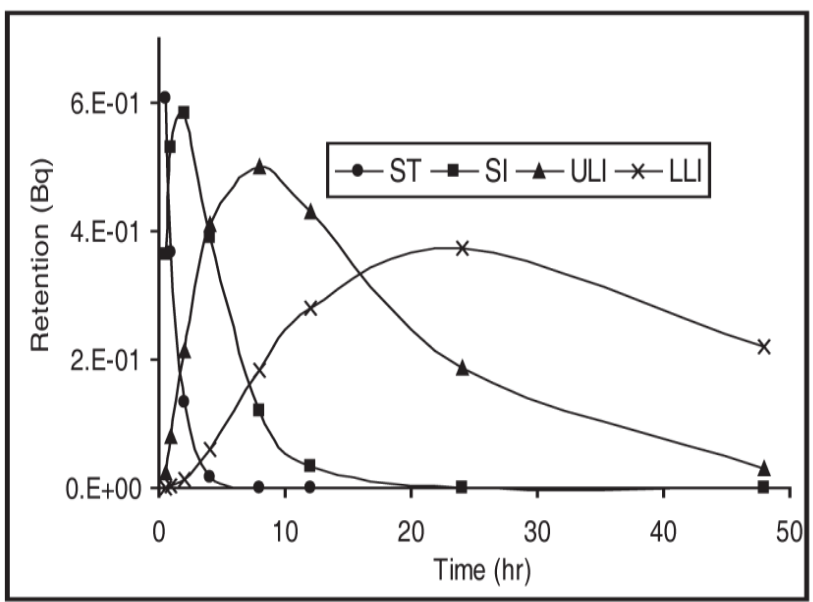

Figure 2. Variation of retention with timec

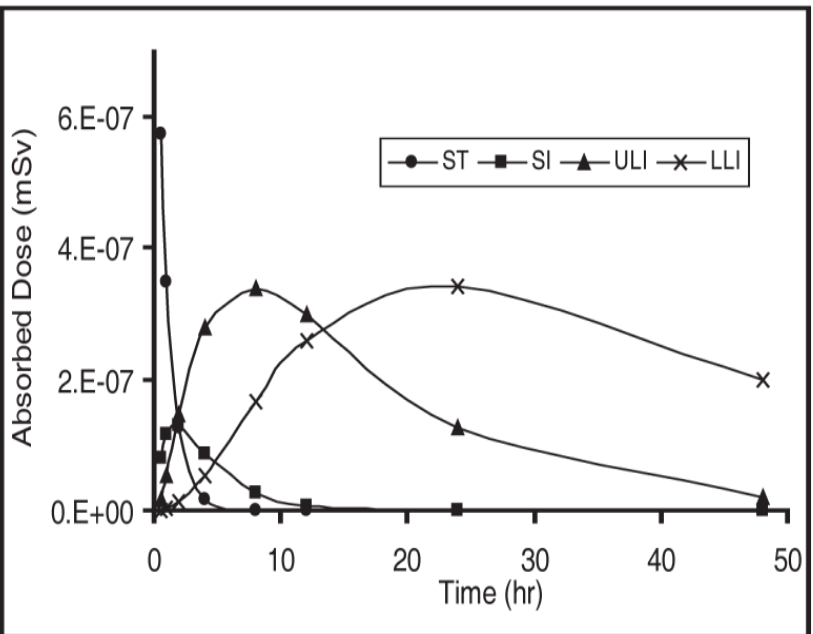

Figure 3. Variation of absorbed dose with time for 1 year old child

Absorbed dose rate in different $\mathrm{t}$ tissue compartment are mentioned below:

Stomach: Initial falling rate: 1 x $10^{-6} \mathrm{mSv}$ per $\mathrm{hr}$ (between $0.5 \mathrm{hr}$ and $1 \mathrm{hr}$ ).

Small Intestine: Initial rising rate: 1.64 x 10-8 mSv per hr. $2 \mathrm{hr}$ after ingestion the absorbed dose reaches to the highest value $\left(2.83 \times 10^{-8} \mathrm{mSv}\right)$. Initial falling rate of dose from the organ: $4.65 \times 10^{-9} \mathrm{mSv}$ per $\mathrm{hr}$ (between $2 \mathrm{hr}$ and $4 \mathrm{hr}$ ).
Upper Large Intestine: Initial dose rising rate is $2.1 \mathrm{x}$ 10-8 $\mathrm{mSv}$ per hr (between $0.5 \mathrm{hr}$ and $1 \mathrm{hr}$ ). Maximum absorbed dose $\left(9.6 \times 10^{-8} \mathrm{mSv}\right)$ value attained after $8 \mathrm{hrs}$ of ingestion. Initial falling rate of dose from this tissue is $3.47 \times 10^{-9} \mathrm{mSv}$ per $\mathrm{hr}$ (between $8 \mathrm{hr}$ and $12 \mathrm{hr}$ ).

Lower Large Intestine: Initially absorbed dose rises in LLI at $9.7 \times 10^{-10} \mathrm{mSv}$ per hr (between $0.5 \mathrm{hr}$ and $1 \mathrm{hr}$ ). Maximum absorbed dose attained in this tissue is $9.6 \mathrm{x}$ 10-8 $\mathrm{mSv}$. Time after which the maximum dose value has been deposited in the organ is $24 \mathrm{hrs}$ of ingestion. The average falling rate of dose from LLI is $1.62 \times 10^{-9} \mathrm{mSv}$ per hr (between $24 \mathrm{hrs}$ and $48 \mathrm{hrs}$ ). The absorbed dose values in different compartments are displayed in figure 7 to 9 . The variation of dose rates and maximum absorbed dose in different compartments are also shown in Table 2.

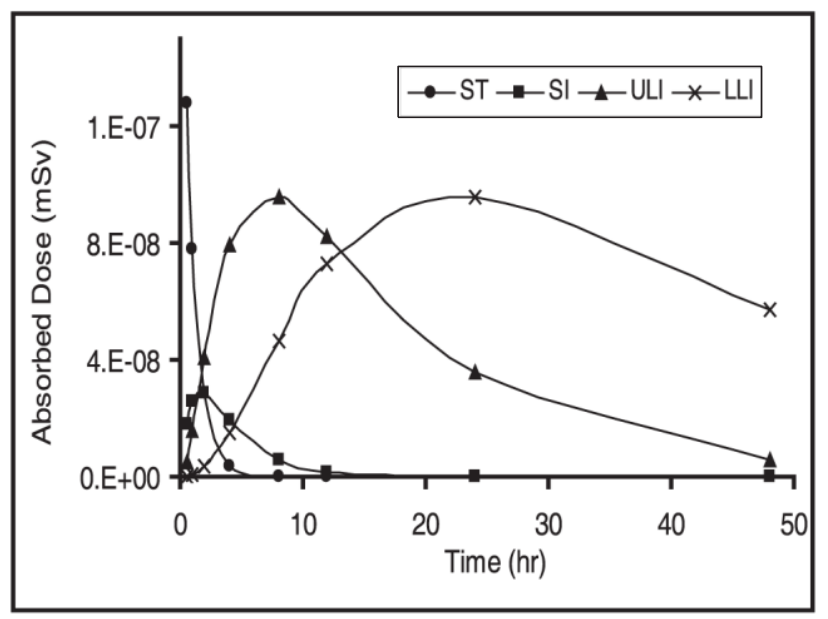

Figure 4 Variation of absorbed dose with dose with time for 10 years old subject

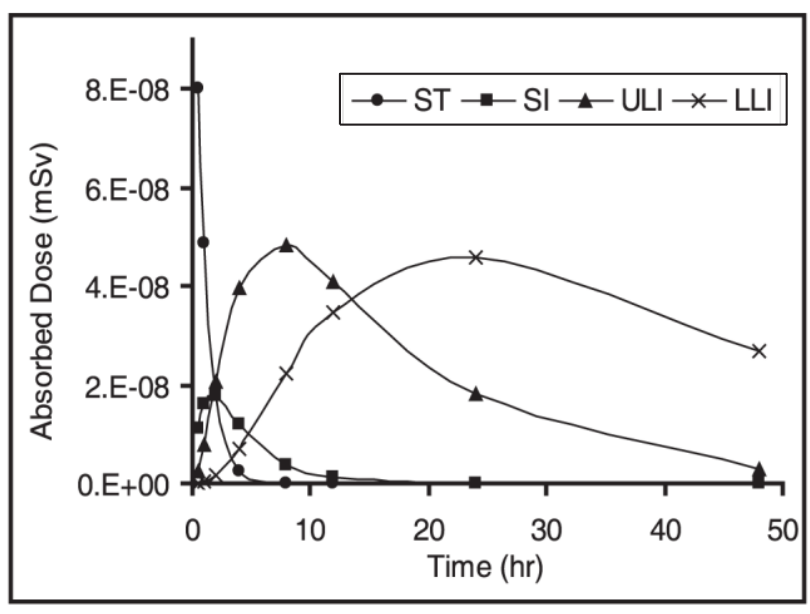

Figure 5 Variation of absorbed time for Adult Female 


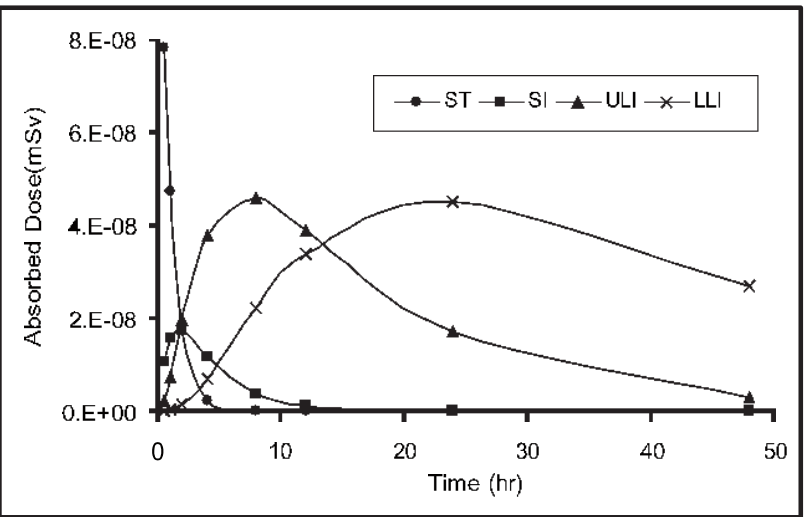

Figure 6 Variation of absorbed dose with time for Adult Male

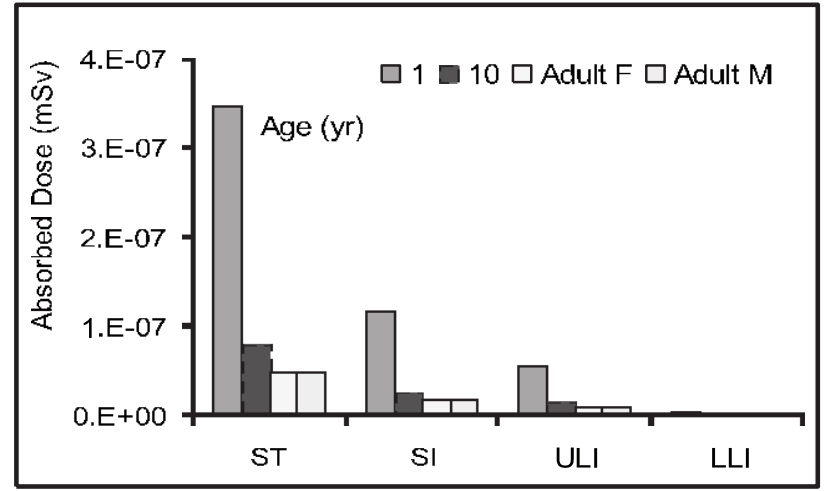

Figure 7 Absorbed dose in different compartments after 1hr of intake

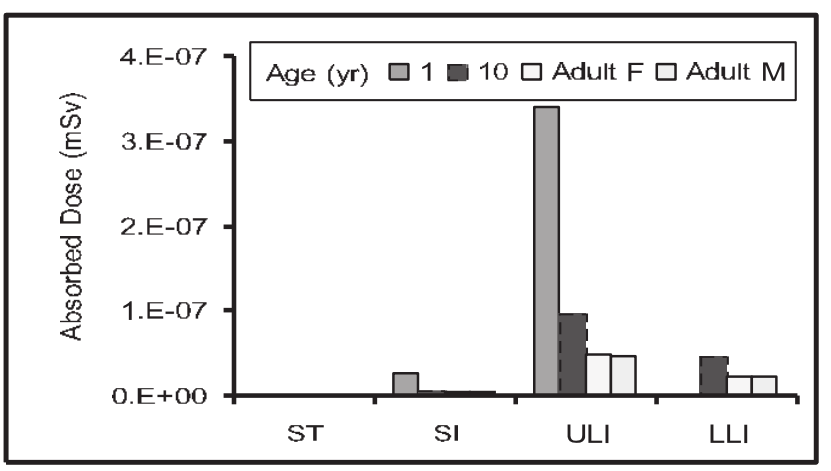

Figure 8. Absorbed dose in different Compartments after $8 \mathrm{hrs}$ of intake

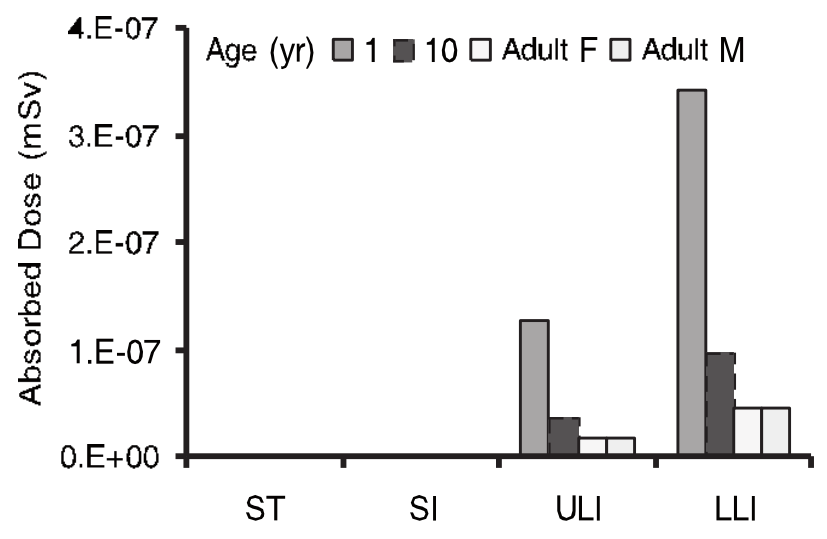

Figure9Absorbeddosein different compartmentsafter 24hsof intake

Table1: Variation of dose rate measured $(\mathrm{mSv} / \mathrm{hr})$ in different compartments of GI tract

\begin{tabular}{|c|c|c|c|c|c|c|c|c|c|c|c|c|}
\hline \multirow{2}{*}{$\begin{array}{l}\text { Compart. } \\
\text { of GI tract }\end{array}$} & \multicolumn{3}{|c|}{1 year } & \multicolumn{3}{|c|}{10 years } & \multicolumn{3}{|c|}{ Adult Male } & \multicolumn{3}{|c|}{ Adult Female } \\
\hline & $\begin{array}{l}\text { Rising } \\
\text { Rate }\end{array}$ & $\begin{array}{l}\text { Falling } \\
\text { Rate }\end{array}$ & $\begin{array}{l}\text { Max. } \\
\text { Dose }\end{array}$ & $\begin{array}{l}\text { Rising } \\
\text { Rate }\end{array}$ & $\begin{array}{l}\text { Falling } \\
\text { Rate }\end{array}$ & $\begin{array}{l}\text { Max. } \\
\text { Dose }\end{array}$ & $\begin{array}{l}\text { Rising } \\
\text { Rate }\end{array}$ & $\begin{array}{l}\text { Falling } \\
\text { Rate }\end{array}$ & $\begin{array}{l}\text { Max. } \\
\text { Dose }\end{array}$ & $\begin{array}{l}\text { Rising } \\
\text { Rate }\end{array}$ & $\begin{array}{l}\text { Falling } \\
\text { Rate }\end{array}$ & $\begin{array}{l}\text { Max. } \\
\text { Dose }\end{array}$ \\
\hline $\begin{array}{l}\text { ST } \\
\end{array}$ & NA & $\begin{array}{l}4.52 \times \\
10^{-7}\end{array}$ & $*$ & NA & $\begin{array}{l}1 \mathrm{x} \\
10^{-6}\end{array}$ & $*$ & $\mathrm{NA}$ & $\begin{array}{l}6.16 \mathrm{x} \\
10^{-8}\end{array}$ & $*$ & $\mathrm{NA}$ & $\begin{array}{l}6.28 \mathrm{x} \\
10^{-8}\end{array}$ & $*$ \\
\hline SI & $\begin{array}{l}7.34 \mathrm{x} \\
10^{-8}\end{array}$ & $\begin{array}{l}2.13 \mathrm{x} \\
10^{-8}\end{array}$ & $\begin{array}{ll}1.29 & \mathrm{x} \\
10^{-7} & \\
\end{array}$ & $\begin{array}{l}1.64 x \\
10^{-8}\end{array}$ & $\begin{array}{l}4.65 \times \\
10^{-9}\end{array}$ & $\begin{array}{l}2.83 \mathrm{x} \\
10^{-8}\end{array}$ & $\begin{array}{l}1 x \\
10^{-8}\end{array}$ & $\begin{array}{l}2.85 \mathrm{x} \\
10^{-9}\end{array}$ & $\begin{array}{l}1.73 x \\
10^{-8}\end{array}$ & $\begin{array}{l}1.02 \times \\
10^{-8}\end{array}$ & $\begin{array}{l}2.95 \mathrm{x} \\
10^{-9}\end{array}$ & $\begin{array}{l}1.78 \times \\
10^{-8}\end{array}$ \\
\hline ULI & $\begin{array}{l}7.52 x \\
10^{-8}\end{array}$ & $\begin{array}{l}1.23 \times \\
10^{-9}\end{array}$ & $\begin{array}{ll}3.39 & \mathrm{x} \\
10^{-7} & \\
\end{array}$ & $\begin{array}{l}2.1 \mathrm{x} \\
10^{-8}\end{array}$ & $\begin{array}{l}3.47 \times \\
10^{-9}\end{array}$ & $\begin{array}{l}9.6 \mathrm{x} \\
10^{-8}\end{array}$ & $\begin{array}{l}1.01 \mathrm{x} \\
10^{-8}\end{array}$ & $\begin{array}{l}1.67 x \\
10^{-9}\end{array}$ & $\begin{array}{l}4.59 \times \\
10^{-8}\end{array}$ & $\begin{array}{l}1.07 \mathrm{x} \\
10^{-8}\end{array}$ & $\begin{array}{l}1.72 \times \\
10^{-9}\end{array}$ & $\begin{array}{l}4.82 \times \\
10^{-8}\end{array}$ \\
\hline LLI & $\begin{array}{l}3.46 \mathrm{X} \\
10^{-9}\end{array}$ & $\begin{array}{l}5.75 \mathrm{x} \\
10^{-9}\end{array}$ & $\begin{array}{ll}3.42 & \mathrm{x} \\
10^{-7} & \end{array}$ & $\begin{array}{l}9.7 \mathrm{x} \\
10^{-10}\end{array}$ & $\begin{array}{l}1.62 \times \\
10^{-9}\end{array}$ & $\begin{array}{c}9.6 \mathrm{x} \\
10^{-8}\end{array}$ & $\begin{array}{l}4.55 \quad x \\
10^{-10}\end{array}$ & $\begin{array}{l}7.5 \mathrm{x} \\
10^{-10}\end{array}$ & $\begin{array}{l}4.5 \mathrm{x} \\
10^{-8}\end{array}$ & $\begin{array}{l}4.636 \mathrm{x} \\
10^{-10}\end{array}$ & $\begin{array}{l}7.7 x \\
10^{-10}\end{array}$ & $\begin{array}{l}4.58 \mathrm{x} \\
10^{-8}\end{array}$ \\
\hline
\end{tabular}

Compart.: Compartment,

NA: Not Applicable

* Calculations have been done considering $t=0$ when stomach absorbs maximum dose. 
Committed equivalent doses for different age groups have been given in Table2

Table 2: Committed equivalent dose ( $\mathrm{mSv})$

\begin{tabular}{|l|l|l|l|l|}
\hline $\begin{array}{l}\text { Parts of GI } \\
\text { tract }\end{array}$ & 1 year & 10 years & $\begin{array}{l}\text { Adult } \\
\text { femalc }\end{array}$ & Adult male \\
\hline ST & $3.40 \times 10^{-3}$ & $7.61 \times 10^{-4}$ & $4.75 \times 10^{-4}$ & $4.64 \times 10^{-4}$ \\
\hline SI & $2.88 \times 10^{-3}$ & $6.33 \times 10^{-4}$ & $3.98 \times 10^{-4}$ & $3.86 \times 10^{-4}$ \\
\hline ULI & $2.93 \times 10^{-2}$ & $8.31 \times 10^{-3}$ & $4.18 \times 10^{-4}$ & $3.97 \times 10^{-3}$ \\
\hline LLI & $6.32 \times 10^{-2}$ & $1.77 \times 10^{-2}$ & $8.47 \times 10^{-3}$ & $8.32 \times 10^{-3}$ \\
\hline
\end{tabular}

The committed effective dose for GI tract are found to be $6.03 \times 10^{-3} \mathrm{mSv} / \mathrm{Bq}, 1.67 \times 10^{-3} \mathrm{mSv} / \mathrm{Bq}, 8.26 \times$ $10^{-4} \mathrm{mSv} / \mathrm{Bq}$ and $8.03 \times 10^{-4} \mathrm{mSv} / \mathrm{Bq}$ for age groups 1 year, 10 years, adult female and adult male respectively.

In case of different ages, absorbed dose is the highest for the 1 year aged child; next one is for the 10 year old subject followed by the adult female and finally the adult male. With age the absorption of dose reduces. This observation is true for each type of tissue. The cause is the dependence of absorption of tissue mass. The variation of committed equivalent dose at the different compartments of GI tract for the above mentioned age groups is LLI $>\mathrm{ULI}>\mathrm{ST}>\mathrm{SI}$. In this work possibility of gender dependence of the absorbed dose rate has been investigated. The committed equivalent and committed effective dose in the GI tract of female is greater than male.

\section{CONCLUSION}

Patient-specific internal radiation doses in different parts of GI tract have been calculated by using locally developed IRDA software. Results of this study will be useful for monitoring internal exposures of workers for assessing committed effective doses from estimated intakes of radioactive material. The following important observations could be made from the study.

a. The absorbed dose for children has been observed to be higher than that of others having higher body mass. This is justified, since absorbed dose is inversely proportional to the mass of the tissue compartment of GI tract. Regarding age the variation of absorbed dose, committed equivalent dose and committed effective dose follows the sequence: 1 year $>10$ years $>$ adult female $>$ adult male .

b. Regarding tissue compartments the variation pattern of committed equivalent dose is LLI > ULI $>$ ST > SI.

c. The highest committed effective dose per unit intake of Ra-226 radionuclide is found in the GI tract of 1 year old child.

\section{REFERENCES}

1. ICRP (International Commission on Radiological Protection), Limits for Intakes of Radionuclides by Workers: Part 1, Publication 30, Pergamon Press, Oxford and New York, 1979.

2. ICRP (International Commission on Radiological Protection), Age-dependent Doses to Members of the Public from Intake of Radionuclides: Part 1, Publication 56, Pergamon Press, Oxford and New York, 1989.

3. ICRP (International Commission on Radiological Protection), Age-dependent Doses to Members of the Public from Intake of Radionuclides: Part 4, Inhalation Dose Coefficients, Publication 71, Pergamon Press, Oxford and New York, 1995.

4. Quddus AHMR, Iqbal SM, Zaman MMA and Mollah AS Development of IRDA Software for the Calculation of Internal Radiation Dose. Bangladesh Journal of Nuclear Medicine 2010;13(1)25-28.

5. Quddus AHMR, 2010, Assessment of Internal Radiation Doses due to Intake of Radionuclides by Ingestion in Human Body, Ph. D. thesis, pp 56-66. 